\title{
Article \\ The Potential Global Climate Suitability of Kiwifruit Bacterial Canker Disease (Pseudomonas syringae pv. actinidiae (Psa)) Using Three Modelling Approaches: CLIMEX, Maxent and Multimodel Framework
}

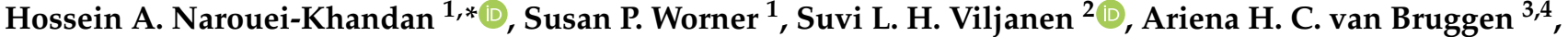 \\ Giorgio M. Balestra ${ }^{5}$ and Eirian Jones ${ }^{6}$ (D)
}

check for updates

Citation: Narouei-Khandan, H.A.; Worner, S.P.; Viljanen, S.L.H.; van Bruggen, A.H.C.; Balestra, G.M.; Jones, E. The Potential Global Climate Suitability of Kiwifruit Bacterial Canker Disease (Pseudomonas syringae pv. actinidiae (Psa)) Using Three Modelling Approaches: CLIMEX, Maxent and Multimodel Framework. Climate 2022, 10, 14. https://doi.org/ $10.3390 /$ cli10020014

Academic Editor: Forrest M. Hoffman

Received: 31 December 2021

Accepted: 24 January 2022

Published: 28 January 2022

Publisher's Note: MDPI stays neutral with regard to jurisdictional claims in published maps and institutional affiliations.

Copyright: (C) 2022 by the authors. Licensee MDPI, Basel, Switzerland. This article is an open access article distributed under the terms and conditions of the Creative Commons Attribution (CC BY) license (https:// creativecommons.org/licenses/by/ $4.0 /)$.
1 Bio-Protection Research Centre, Lincoln University, Lincoln 7674, New Zealand; susan.worner@lincoln.ac.nz

2 The New Zealand Institute for Plant \& Food Research Limited, Private Bag 4704, Christchurch 8140, New Zealand; suvi.viljanen@plantandfood.co.nz

3 Department of Plant Pathology, University of Florida, Gainesville, FL 32611, USA; ahcvanbruggen@ufl.edu

4 Emerging Pathogens Institute, University of Florida, Gainesville, FL 32611, USA

5 Departments of Agriculture and Forestry Science (DAFNE), University of Tuscia, 01100 Viterbo, Italy; balestra@unitus.it

6 Department of Pest-Management and Conservation, Faculty of Agriculture and Life Sciences, Lincoln University, Lincoln 7674, New Zealand; eirian.jones@lincoln.ac.nz

* Correspondence: hossein.khandan@mpi.govt.nz

\begin{abstract}
In recent years, outbreaks of kiwifruit bacterial canker (Pseudomonas syringae pv. actinidiae, Psa) have caused huge economic losses to two major global kiwifruit producers, Italy and New Zealand. To evaluate the potential global risk areas of Psa, three modelling methods (MaxEnt, CLIMEX and a Multi-Model Framework, including Support Vector Machine or SVM) were used. Current global occurrence data for Psa were collected from different sources. The long-term climate data were sourced from WorldClim and CliMond websites. The model results were combined into a consensus model to identify the hotspots. The consensus model highlighted the areas where two or three models agreed on climate suitability for Psa. All three models agreed with respect to the climate suitability of areas where Psa is currently present and identified novel areas where Psa has not established yet. The SVM model predicted large areas in Central Asia, Australia, and Europe as more highly suitable compared to MaxEnt and CLIMEX. Annual mean temperature and annual precipitation contributed most to the MaxEnt prediction. Both MaxEnt and CLIMEX showed the probability of Psa establishment increased above $5{ }^{\circ} \mathrm{C}$ and decreased above $20^{\circ} \mathrm{C}$. The annual precipitation response curve showed that excessive rain $(>1200 \mathrm{~mm} / \mathrm{y})$ constrains Psa establishment. Our modelling results will provide useful information for Psa management by highlighting the climatically susceptible areas where Psa has not established, such as the USA, Iran, Denmark, Belgium and especially South Africa, where kiwifruit has been planted commercially in recent years.
\end{abstract}

Keywords: kiwifruit bacterial canker; Psa; climate suitability; CLIMEX; MaxEnt; Multi-Model Framework (MMF)

\section{Introduction}

The causal agent of bacterial canker of kiwifruit, Pseudomonas syringae pv. actinidiae (Psa) is a Gram-negative, obligate aerobic bacterium. Symptoms of the disease mainly appear at the beginning of spring when leaf spots become visible, appearing brown surrounded by a bright chlorotic halo [1]. Floral buds may turn brown and exude gum without opening. Translucent exudate on otherwise healthy tissues, such as canes, is also considered to be one of the main symptoms of Psa on kiwifruit (Figure 1a-d) [1-3]. 

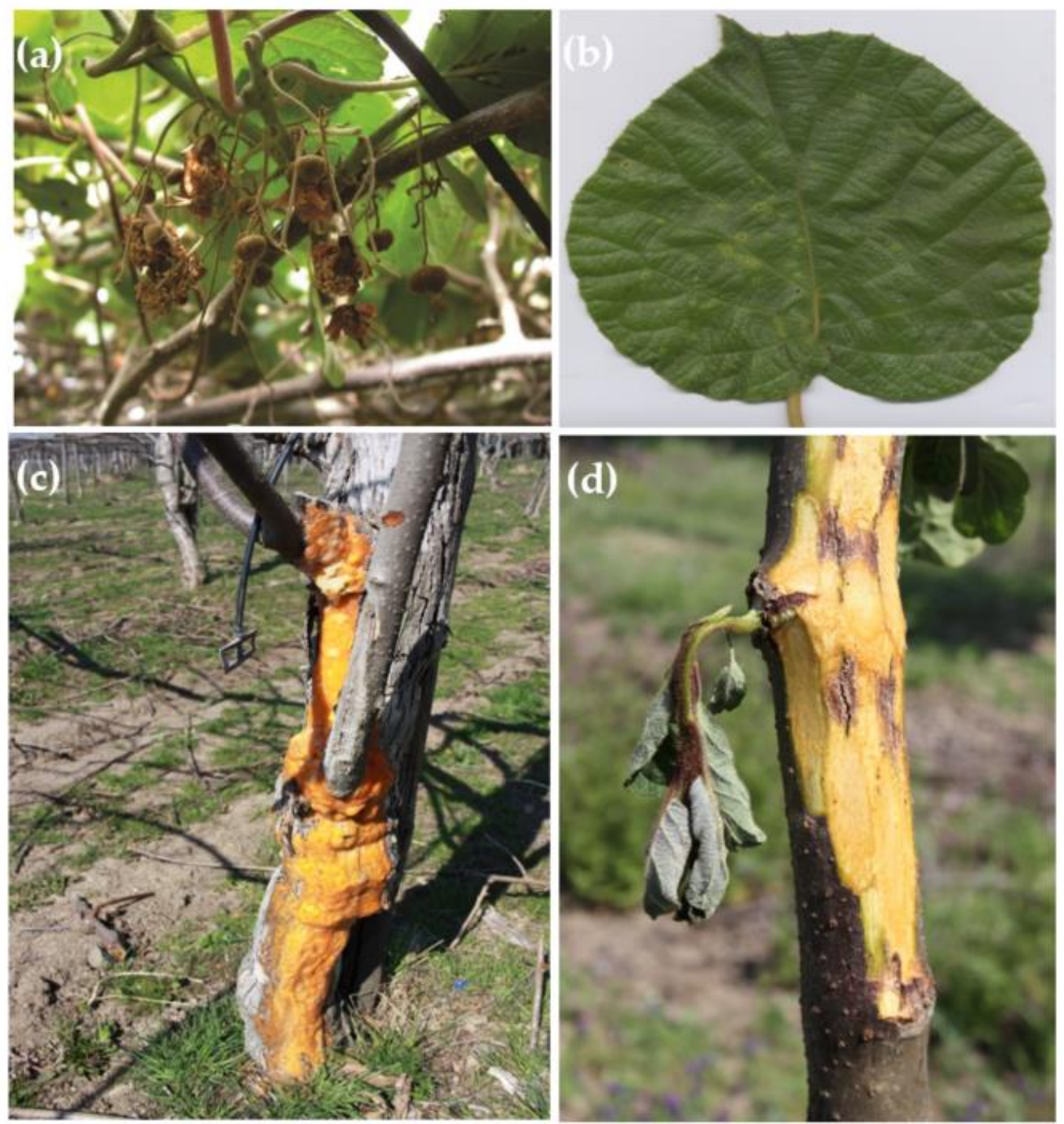

Figure 1. Pseudomonas syringae pv. actinidiae (Psa) symptoms on kiwifruit (a) buds and flowers (b) leaf (c) trunk (exudate) (d) new shoot. Photos' credit: G.M. Balestra.

Psa was first isolated from kiwifruit in Japan in 1984 and described as a new pathovar in 1989 [4]. In the late 1980s, Psa was reported from Korea [5] and from China in 1990 [6].

Psa was first detected outside Asia in 1994, in Italy, the world's major producer of kiwifruit. It remained sporadic and with low incidence there until 2008, when a serious outbreak occurred [7-10]. During the following years, Psa continued to spread into Portugal [9,11], Spain [12], New Zealand [13], Chile [14], Slovenia [15], Switzerland [16], Turkey [17], France [18], Germany [19] and Greece in 2014 [20].

Six biovars of Psa have been described worldwide, based on genomic fingerprinting and toxin production (biovars 1-6), though some studies have revealed genetic variability within Psa populations of up to 14 groups [21-23]. However, biovar 4 (Psa-Lv) was later transferred to a new pathovar, Pseudomonas syringae pv. actinidifoliorum (Pfm) [24]. While biovars 1 and 2 are reported to cause moderate damage, biovar 3 is the most virulent form, and has inflicted significant damage in Italy and New Zealand [25]. For example, while the early reports in 2013 stated that $77 \%$ of New Zealand's kiwifruit orchards were infected with Psa [26], the most recent report indicates that this has increased up to 92\% [27].

Psa can infect Actinidia chinensis var. deliciosa (green kiwifruit) and Actinidia chinensis var. chinensis (gold kiwifruit), kiwiberry (Actinidia arguta) and wild Actinidia kolomikta [28]. However, its survival on nonhost plants such as Alternanthera philoxeroides (Caryophyllales: Amaranthaceae), Setaria viridis (Cyperales: Poaceae) and Paulownia fortunei (Scrophulariales: 
Scrophulariaceae) has also been documented [29,30]. In addition, Vanneste et al. (18) reported that Psa can survive on Cryptomeria japonica (Japanese cedar). However, this was achieved by artificial inoculation and no evidence of multiplication was found (Psa populations on $C$. japonica decreased with time). Until the devastating Italian outbreak of 2008 , in which Psa losses were estimated to be $€ 2$ million by 2009, it was assumed that the disease's economic importance was relatively low [31,32]. In New Zealand a 2012 publication estimated that the cost of Psa (as Psa-V) would be NZ\$310-\$410 million in the next five years, and NZ\$740-\$885 million over the next 15 years [33]. However, by 2014, only two years after these estimates, the cost of export losses alone mounted up to NZ\$930 million [34]. Although, estimation of the economic impacts of Psa, or any other plant disease is beneficial, the evaluation of socio-economic and environmental impacts which can be devastating are often rare or ignored. For instance, in New Zealand an early estimation in 2012 claimed that Psa could result in up to 470 full-time job losses per year for the following four years. Such impacts can lead to anxiety and stress which need proper evaluations [33].

Environmental factors such as strong wind and rain are major vectors for introduction into new regions $[9,35]$. In addition to human-mediated spread though grafting materials, nursery materials and pollen, Psa has been shown to be carried by wind and it has also been shown that frequent spring hailstorms cause wounds that contribute to disease spread over large areas [1,25]. Moreover, the role of some sucking insects such as Metcalfa pruinosa (Hemiptera: Flatidae) as vectors of Psa in laboratory conditions has been investigated and confirmed [36].

Information about the epidemiology of the pathogen is limited. It has been reported that at temperatures between $10{ }^{\circ} \mathrm{C}$ and $20^{\circ} \mathrm{C}$, the pathogen is very active [37]. In other studies, the optimum temperature range for growth on new canes is estimated at $12{ }^{\circ} \mathrm{C}$ to $20^{\circ} \mathrm{C}$ and $15{ }^{\circ} \mathrm{C}$ for leaf infection $[6,38,39]$. While studies in Japan and Korea reported very little symptom development at temperatures $>20^{\circ} \mathrm{C}$ during a 10-day period, hightemperature tolerance is generally estimated at $25^{\circ} \mathrm{C}$ in France, Italy, and Portugal $[6,25,40]$. In previous studies, rain has been implicated as the most important factor in establishment and distribution of Psa but no detailed quantitative data are available as yet [41,42].

Despite the huge economic losses attributed to Psa in recent years, there are limited studies that evaluate the risk of its establishment in areas where kiwifruit is commercially grown and Psa has not been reported yet. Therefore, studies that could project the habitat suitability of Psa in noninfected areas can be very valuable. Reynaud et al. (2011, cited in [40]) used CLIMEX software package (version 3.0, CSIRO Publishing, Melbourne, Australia) to evaluate habitat suitability based on cold and dry stress parameters. In a preliminary study with limited data, two models (MaxEnt and CLIMEX) were used to evaluate the potential distribution of Psa, which both showed differences in projections in areas of interest [43]. In a study by Wang et al. [44], MaxEnt was used to model the current and future distribution of Psa in China based on different emission scenarios. They identified that environmental variables such as maximum April temperature, mean temperature of the coldest quarter, precipitation in May and minimum temperature in October contributed the most to the model projection. In a recent study focused on China, [45], an ensemble approach using three correlative models including generalized boosting models (GBM), random forests (RF) and classification tree analysis (CTA) was employed to predict the potential distribution of Psa in China under four general circulation models (GCMs). In all three models, precipitation in March contributed the most to model projection (28.2\%) followed by the mean temperature of the warmest quarter $(17.7 \%)$. Do et al. [46] developed a model to evaluate the accumulated potential damage of Psa on kiwifruit during the growing and overwintering seasons which can be set to run using hourly or daily mean air temperature. While their study was only focused on the green kiwifruit cultivar Hayward (A. chinensis var. deliciosa), they noticed that necrotic lesion length increased with temperature, with the longest observed at $35^{\circ} \mathrm{C}$. Beresford et al. [39] developed a weather-based mechanistic risk model to predict Psa development based on a multiplication and dispersal concept. Their 
model calculated the bacterial multiplication ( $\mathrm{M}$ index) from a temperature function and the daily risk factor ( $\mathrm{R}$ index), which is the three-day accumulation of the $\mathrm{M}$ index on days with total rainfall $>1 \mathrm{~mm} /$ day. They found that the optimum temperature for leaf infection was $21^{\circ} \mathrm{C}$ and $15^{\circ} \mathrm{C}$ in vitro and in planta, respectively. Kim and Koh [47] adapted the same risk model to predict Psa epidemics in Korea. Due to significant differences between the New Zealand and Korean climates, the temperature and rainfall functions of the model were modified. They found that the model was highly sensitive to rainfall, and disease incidence was high when rainfall was recorded in consecutive days. By testing different ranges of average temperatures, $24{ }^{\circ} \mathrm{C}$ was identified as the optimal threshold, with no change in disease incidence when daily maximum temperatures exceeded $27-30{ }^{\circ} \mathrm{C}$. Kim and Koh [48] also developed an integrated modelling approach to investigate the potential for epidemics of Psa under climate change. The integrated modelling approach used three models. First, a climate suitability model was developed which predicted the suitable areas for growing kiwifruit. Then a chill-day model simulated the periods of kiwifruit flowering limited to the suitable areas predicted by the climate suitability model mentioned earlier. Finally, these flowering dates were fed into Pss-KBB model [49] to simulate the potential risk of the epidemic.

Most studies predicting the distribution of Psa rely on a single model, or use the same type of models (e.g., only correlative models or only mechanistic models). Their predictions for some areas are sometimes different or contradictory which can add to the prediction uncertainty. It is therefore important to develop a consensus model which relies on the agreement of different modelling approaches to investigate the risk of Psa globally. In this way, effective readiness and response measures can be employed to minimize the potentially devastating impacts of Psa at locations of interest.

The objectives of the current study are to: (i) model the potential global distribution of kiwifruit bacterial canker (Psa) using ensemble models and model agreement, (ii) investigate agreement among these models' projections to identify the hotspots and estimate how they contribute to a better knowledge of Psa spread and risk; and (iii) characterize the potential environmental variables important in the distribution of Psa.

Three different types of species distribution models (SDMs) were used to address the objectives: The current distribution records of Psa and long-term climate data were used to project the potential distribution using a semimechanistic model (CLIMEX), a presence-background model (MaxEnt) and multimodel framework (MMF). These models have frequently been used in different studies to project the habitat suitability of different invasive species into new areas [50-52].

\section{Materials and Methods}

\subsection{Psa Presence Data}

At first, 324 presence points of Psa were collected from available studies and online sources $[10,11,13,31,35,44]$. In cases where coordinates were not available and only the name of localities of Psa presence were mentioned in literature, ArcGIS Pro v 2.7.3 and Google Earth Pro v. 7.3.4 were used to find the coordinates. Duplicate points were removed based on the resolution of the data (10 arc minute) to minimize the environmental bias and to avoid possible spatially autocorrelated presence points (Figure 2 and Table S1). Finally, 201 points were used in the modelling process. Because there is no reliable information about the environmental needs for infection of kiwifruit vines by different strains or biovars, these strains were not differentiated among the presence records in this study. The records of biovar 4 were not included in this study as they are now proven to belong to a different pathovar [24]. 


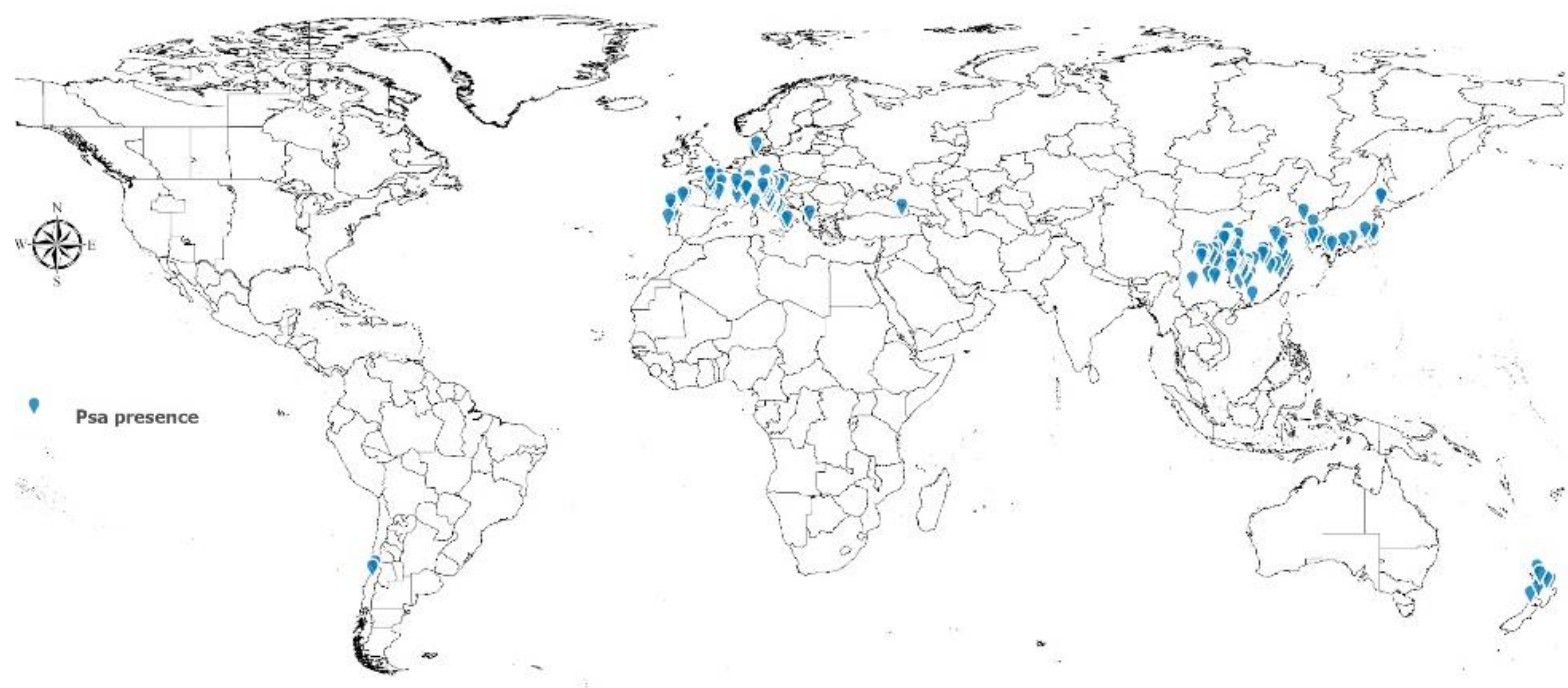

Figure 2. Current global distribution of Kiwifruit bacterial canker disease (Psa).

\subsection{Bioclimatic Variables}

Climate data files (Met manager version 1.2) from CliMond website were downloaded for direct use in CLIMEX software (www.climond.org, accessed on 1 December 2021) [53]. Bioclimatic variables [54] that have been frequently used in species distribution models were sourced from the Worldclim website (Bioclim version 2.1) (www.worldclim.org, accessed on 1 December 2021). This dataset includes 19 variables that were derived from long-term temperature and rainfall data. For correlative models, a pairwise Pearson's correlation test was used to eliminate variables that were highly correlated. This led to selection of 10 variables with a correlation less than 0.75 to be used in the model training process. The variables used in MaxEnt and MMF included annual precipitation, annual mean temperature, minimum temperature of the coldest month, mean diurnal range, maximum temperature of the warmest month, temperature seasonality, precipitation of the coldest quarter, precipitation of the wettest quarter, and precipitation of the wettest month. In addition, variables were screened for ecological relevance [55]. To ensure uniformity among models, gridded climate data with $10^{\prime}$ resolution were used for all modelling approaches.

\subsection{Species Distribution Modelling \\ 2.3.1. CLIMEX}

CLIMEX as a semimechanistic model has been frequently used in plant disease distribution modelling efforts [56-58] and is considered a mechanistic model that enables the user to estimate the potential geographical distribution and seasonal abundance of a species in relation to climate [59-61]. Unlike statistical models, CLIMEX matches the patterns of climate and species' distribution by calibration rather than by a statistical fitting process. The parameter values used in [40] were initially used as starting points to calibrate the model. After adjusting the parameter values iteratively, the model was run repeatedly to achieve the highest ecoclimatic index (EI) values close to the known distribution of Psa and lowest EI values outside the range of Psa reported distribution. These criteria were used to obtain the closest match of suitable habitats projected by CLIMEX and the reported distribution patterns of Psa. The final parameter values used to develop the model are shown in Table 1. Finally, the model was assessed visually based on the match of known presence points and suitable habitat projected by the model. 
Table 1. Parameter values used in developing CLIMEX model for Psa in the current study. The table also shows the parameter values used by the CLIMEX model in the EPPO report [40].

\begin{tabular}{llccc}
\hline Index & Parameters & Current Study & EPPO & Unit \\
\hline $\mathrm{SM}_{0}$ & Lower soil moisture threshold & 0.75 & 0.2 & - \\
$\mathrm{SM}_{1}$ & Lower optimum soil moisture & 0.9 & 0.5 & - \\
$\mathrm{SM}_{2}$ & Upper optimum soil moisture & 2.2 & 1.5 & - \\
$\mathrm{SM}_{3}$ & Upper soil moisture threshold & 3 & 2.5 & - \\
$\mathrm{DV}_{0}$ & Lower temperature threshold & 5 & 10 & ${ }^{\circ} \mathrm{C}$ \\
$\mathrm{DV}_{1}$ & Lower optimum temperature & 12 & 20 & ${ }^{\circ} \mathrm{C}$ \\
$\mathrm{DV}_{2}$ & Upper optimum temperature & 20 & 25 & ${ }^{\circ} \mathrm{C}$ \\
$\mathrm{DV}$ & Upper temperature threshold & 28 & 30 & ${ }^{\circ} \mathrm{C}$ \\
$\mathrm{TTCS}$ & Cold stress temperature threshold & 5 & 2 & ${ }^{\circ} \mathrm{C}$ \\
$\mathrm{THCS}$ & Cold stress temperature rate & -0.00005 & -0.01 & $\mathrm{Week}^{-1}$ \\
$\mathrm{DTCS}$ & Cold stress degree-day threshold & 15 & - & ${ }^{\circ} \mathrm{C}$ \\
$\mathrm{DHCS}$ & Cold stress degree-day rate & -0.0001 & - & $\mathrm{Week}^{-1}$ \\
$\mathrm{TTHS}$ & Heat Stress Temperature threshold & 30 & - & ${ }^{\circ} \mathrm{C}$ \\
$\mathrm{THHS}$ & Heat Stress Temperature rate & 0.0005 & - & $\mathrm{Week}^{-1}$ \\
$\mathrm{SDMS}$ & Dry Stress Threshold & 0.2 & 0.15 & $\mathrm{Week}^{-1}$ \\
$\mathrm{HDS}$ & Dry Stress Rate & -0.005 & -0.02 & $\mathrm{Week}^{-1}$ \\
SMWS & Wet stress threshold (1-10) & 2 & - & - \\
HWS & Wet stress rate & 0.001 & - & Week $^{-1}$ \\
\hline
\end{tabular}

\subsubsection{MaxEnt}

MaxEnt is a presence-only or presence-background model which has been claimed to outperform most of existing modelling approaches [62]. A good explanation of MaxEnt, both with respect to its conceptual basis, its application and advantages can be found in Elith et al. [63]. In this study, suggestions by Merow et al. [64] and Syfert et al. [65] regarding feature selection and sampling bias were taken into account. Because enough presence data were available for Psa to allow model complexity, all available feature types i.e., linear, quadratic, product, threshold, and hinge were used as per the default settings of the MaxEnt model. In addition, to measure the variable importance a Jackknife test was performed. The response curves of the predictor variables were produced using available options in MaxEnt to investigate the dependency of predicted suitability on the selected variables. To validate the model output, MaxEnt was set to randomly use 75 percent of the presence data for training and 25 percent for testing the output.

\subsubsection{Multimodel Framework}

The multimodel framework was used to model species presence/absence data by seven different species distribution models: logistic regression (LOG), naive Bayes (NB), classification and regression trees (CART), conditional trees (CTREE), K-nearest neighborhood (KNN), support vector machines (SVM), and artificial neural networks (NNET). These models have been well-used in ecological studies and detailed descriptions about them can be found in the general literature on species distribution models [54]. All seven models were trained (or fitted) and tested using selected variables. The multimodel framework uses one-class support vector machines (OCSVMs) to select appropriate absence points out of large datasets. Instead of selecting a single best performing OCSVM model that can result in over-fitting, a set (an ensemble) of 100 models which had the lowest prediction errors were chosen to profile the background data. Pseudoabsence points were then selected from sites that were assigned 0 (probability of occurrence) on the profiled background data. As there were still many possible absence locations after this analysis, the generated pseudoabsence points were reduced by clustering locations that had similar environmental variables by a defined number of clusters to balance the number of presence locations [66].

Following the selection of the pseudoabsence data by the model, ten selected bioclimatic variables mentioned earlier were used in all seven models. Model validation was carried out to test the ability of the models to predict new data. This was done by bootstrap- 
ping (resampling data) and cross-validation (10-fold) to generate independent validation data. Model predictions were plotted globally. The predicted maps were exported in ASCII format for visualization ArcGIS Pro.

\subsection{Model Consensus (Agreement)}

The locations where all three models agreed on suitability of Psa establishment were identified by converting the three predicted maps into binary maps. To create the binary maps, the occurrence threshold of 0.5 , the threshold of 10 percentile presence in the training data, and an Ecoclimatic Index (EI) threshold of $>1$ were used for, MMF, MaxEnt and CLIMEX, respectively $[50,66,67]$. These binary maps were then overlaid using "equal to Frequency" tool in ArcgGIs Pro to visualize the hotspots.

\section{Results}

\subsection{Model Performance}

According to the current distribution of Psa, the CLIMEX model represented a good fit to the presence data. Table 1 shows the final parameter values used in the current study and those used in an earlier study [40]. The parameter values in [40] and [43] were used as starting points and the current values were obtained through iterative calibration until the map projection fitted the current distribution of Psa. The resultant parameter values were also checked for biological feasibility.

For MaxEnt, the area under the curve (AUC) was used to measure model performance. The AUC of both training and test data for the Psa model was 0.98, which indicates MaxEnt was able to discriminate the data very well (Figure S1).

Multimodel, as an ensemble framework, produces a table of ten different performance criteria, which are separately ranked, and an overall score is calculated from these rankings to find the best-performing model. These performance criteria include accuracy, precision, sensitivity (recall), F.Score, Kappa index, specificity, true statistic skill (TSS) uncertainty, CV. error and AUC. A detailed description of these criteria can be found in [66]. Table S2 shows the variability of the model's performance according to ten performance criteria calculated by cross-validation and bootstrapping. Although variability among modelling methods is expected, there was a low overall variation in the performance among all nine models in MMF. For Psa, the model which had the highest rank in both validation methods was SVM, the results of which are interpreted and used for further analysis here.

\subsection{Predictor (Environmental) Variables}

According to CLIMEX model, the lower temperature threshold (DV0) was $5{ }^{\circ} \mathrm{C}$, which is lower than the $8-10^{\circ} \mathrm{C}$ that has been reported in similar studies [37,40]. In addition, the upper temperature threshold obtained was $28{ }^{\circ} \mathrm{C}$ which was higher than reported values in previous studies $\left(25^{\circ} \mathrm{C}\right)$ and those achieved by MaxEnt in this study [6]. These differences are expected as reported temperature thresholds are based on experiments conducted in controlled conditions [37].

By removing highly correlated variables through the Pearson correlation test ( $>75 \%)$, ten variables mentioned in the Methods section were used in MaxEnt ad MMF. The variable contribution analysis by MaxEnt showed that annual precipitation and annual mean temperature contributed the most to the model prediction followed by minimum temperature of the coldest month (Table 2). 
Table 2. Average contribution (out of 5000 iterations) of environmental variables to the prediction of the global distribution of Psa using MaxEnt.

\begin{tabular}{lcc}
\hline Variable & Percent Contribution & Permutation Importance \\
\hline Annual_Precipitation & 26.7 & 5.6 \\
\hline An_Mean_Tem & 19 & 79.1 \\
\hline Min_Tem_Coldest_Month & 15.9 & 3.4 \\
\hline Mean_Tem_Coldest_Quarter & 15.8 & 0.3 \\
\hline Mean_Diurnal_Range & 10.5 & 6.4 \\
\hline Max_Tem_Warmest_Month & 8.6 & 1.9 \\
\hline Temperature_Seasonality & 2.2 & 1 \\
\hline Precipitation_Coldest_Quarter & 1.1 & 1.6 \\
\hline Precipitation_Wettest_Quarter & 0.1 & 0.5 \\
\hline Precipitation_Wettest_Month & 0 & 0.1 \\
\hline
\end{tabular}

The Jackknife test implied that certain variables such as mean annual temperature (An_Mean_Temp), mean temperature of the coldest month (Mean_Temp_Coldest_Month), minimum temperature of the coldest month and annual precipitation were the most important variables and provided a reasonably good fit to the training data (Figure S2). Furthermore, Figure S2 showed that no variable contained significantly useful information that was not previously included within the other variables. Compared to other variables, the gain in training data experienced a slight decrease when mean diurnal range was removed from the process of training data.

The response curves of some important variables such as mean annual temperature and annual precipitation showed the dependence of predicted suitability on both selected variables. For example, Figure $3 \mathrm{~A}$ indicates a mean annual temperature of around $17^{\circ} \mathrm{C}$ resulted in the highest probability of Psa presence which was in accordance with the CLIMEX results for the lower optimum temperature range (DV1-DV2) and that reported in the literature [37]. There was also a gradual drop in probability of Psa presence at temperatures above $17^{\circ} \mathrm{C}$ and around $24^{\circ} \mathrm{C}$ the probability of Psa presence became zero, which is in accordance with the report that Psa growth decreases at temperatures higher than $25^{\circ} \mathrm{C}$ [37]. The response curve of annual precipitation (cbio12) indicated that excessive rain ( $>1200 \mathrm{~mm} /$ year) can decrease the probability of Psa presence (Figure 3B).

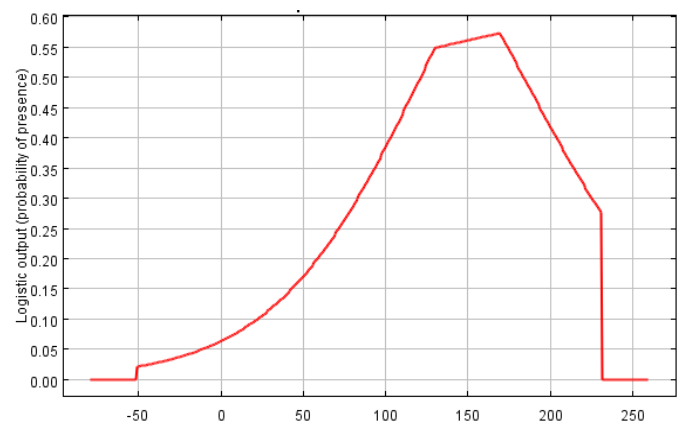

A. Annual mean temperature $\left({ }^{\circ} \mathrm{C}\right)$

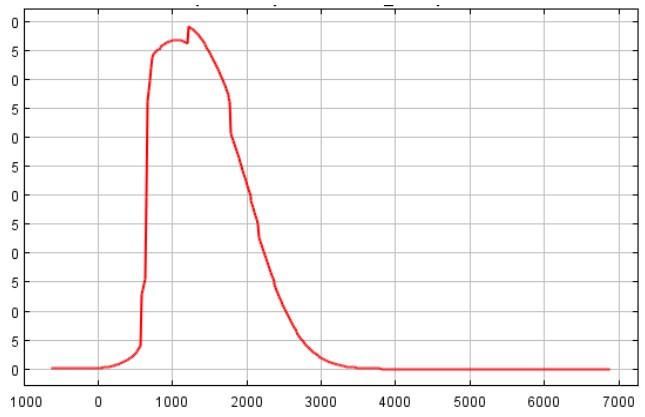

B. Annual preciptation (mm)

Figure 3. The probability of kiwifruit bacterial canker disease (Psa) establishment in response to annual mean temperature (A) and annual precipitation (B) according to the model developed by MaxEnt.

\subsection{Potential Distribton}

Large areas in China, United States, Europe and South America were predicted as suitable by all three models (Figure $4 \mathrm{a}-\mathrm{c}$ ). Nevertheless, there were noticeable discrepancies 
among the models' projections in some areas such as southeastern parts of the USA, Eastern Europe, Central Asia, and South America. In North America, while both MaxEnt and CLIMEX projected large areas in southeastern states of the United States as highly suitable, MMF did not project these areas as suitable and instead northern parts of United States were predicted as highly suitable. California was projected as highly suitable by all three models, in particular in the kiwifruit orchards centered in the Sacramento Valley. In South America, the most extensive areas that were projected as highly suitable for Psa were located around Buenos Aires and Mar del Planta in Argentina. In addition, MMF prediction for Argentina extended further south (around Comodoro Rivadavia) while these areas were not predicted as highly suitable by MaxEnt and CLIMEX. In addition to Argentina, the whole of Uruguay and southern Brazil were also projected as highly suitable. In Chile (where kiwifruit is grown), from Puerto Montt to Santiago were predicted highly suitable by all models.

Central Asia was not predicted as suitable by MaxEnt and CLIMEX and Eastern Europe was predicted marginally suitable, while MMF projected Central Asia and larger areas in Europe (extending toward Eastern Europe) as highly suitable. All models projected Japan and most parts of South Korea as suitable which agrees with current reports of the disease from these regions. All three models projected that northern parts of Iran where kiwifruit is grown commercially were highly suitable. Kiwifruit is also grown in a few orchards in some countries such as Laos, Philippines, Cambodia, Vietnam, India and Bangladesh. Among those countries only Laos was predicted suitable by all three models.

In Africa, some coastal areas in Morocco and Algeria were projected as highly suitable by all three models, but kiwifruit is not currently grown in these areas. Kiwifruit have been cultivated in South Africa only recently and all models project areas around Cape Town and Durban as highly suitable for long-term establishment of Psa.

In Australia, all three models predicted the southeast coastal areas such as Victoria are highly suitable, although so far only Psa-LV (biovar 4) has been reported from these areas [68]. Perth in Western Australia, where kiwifruit is grown on a small scale, was also projected as highly suitable for Psa by all models.

In New Zealand, the North Island was predicted highly suitable for Psa establishment by all three models with all areas having EI values greater than 25 according to the CLIMEX model. While SVM and CLIMEX projected large areas in both North Island and South Island of New Zealand as highly suitable, MaxEnt projection for the South Island was limited to northern parts around Nelson. The prediction agrees with the current distribution of Psa in New Zealand. The weekly growth index chart produced by CLIMEX (Figure 5) shows that on most days of the year, Psa can establish in the Bay of Plenty, an important kiwifruit growing area, although the most suitable periods seem to be March-April and October-December. This higher growth index in winter was in accordance with peaks of Psa reported in New Zealand (www.kvh.org.nz, accessed 1 December 2021). In summary, all kiwifruit growing areas in New Zealand lie within the suitable category of CLIMEX confirming that New Zealand is highly suitable for long-term establishment of Psa.

\subsection{Model Consensus}

The consensus model highlighted the areas (hotspots) that all models agreed on suitability of Psa establishment (Figure 6). From 201 presence points, 199 points were located in areas where all three models agreed on suitability. The remaining two points (in Sichuan (China) and Gijon (Spain)) were located in areas predicted suitable by two models. Areas that were predicted as suitable by all three models included New Zealand, Australia, large areas of southern and southeast China, Japan, South Korea, large areas of Europe, Turkey, coastal areas of South Africa, California, Chile, Southern Brazil, Uruguay, and Buenos Aires in Argentina. 

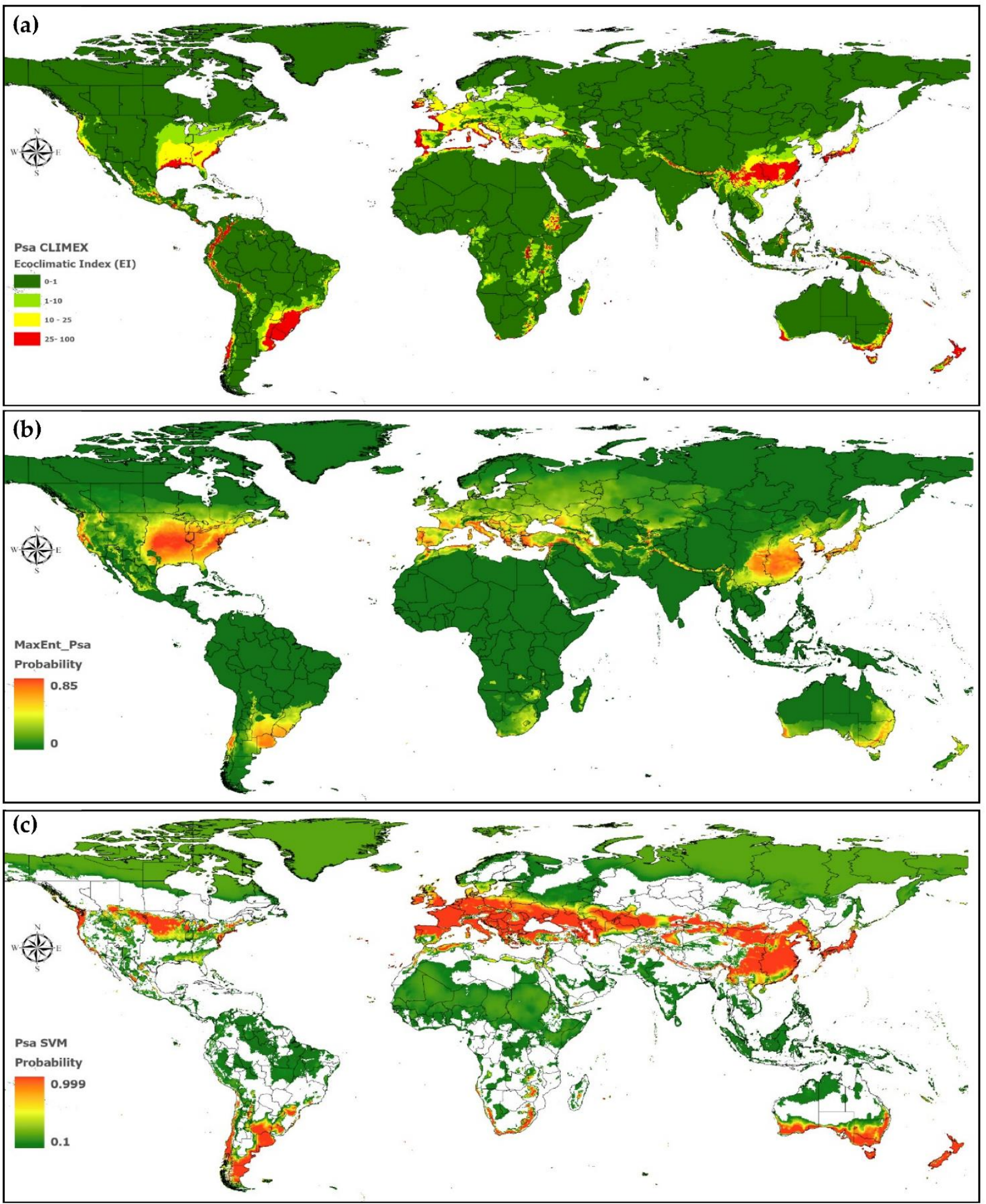

Figure 4. Potential climate suitability of kiwifruit bacterial canker disease at global scale projected by (a) CLIMEX, (b) MaxEnt, (c) support vector machine (SVM from multi-model framework). 


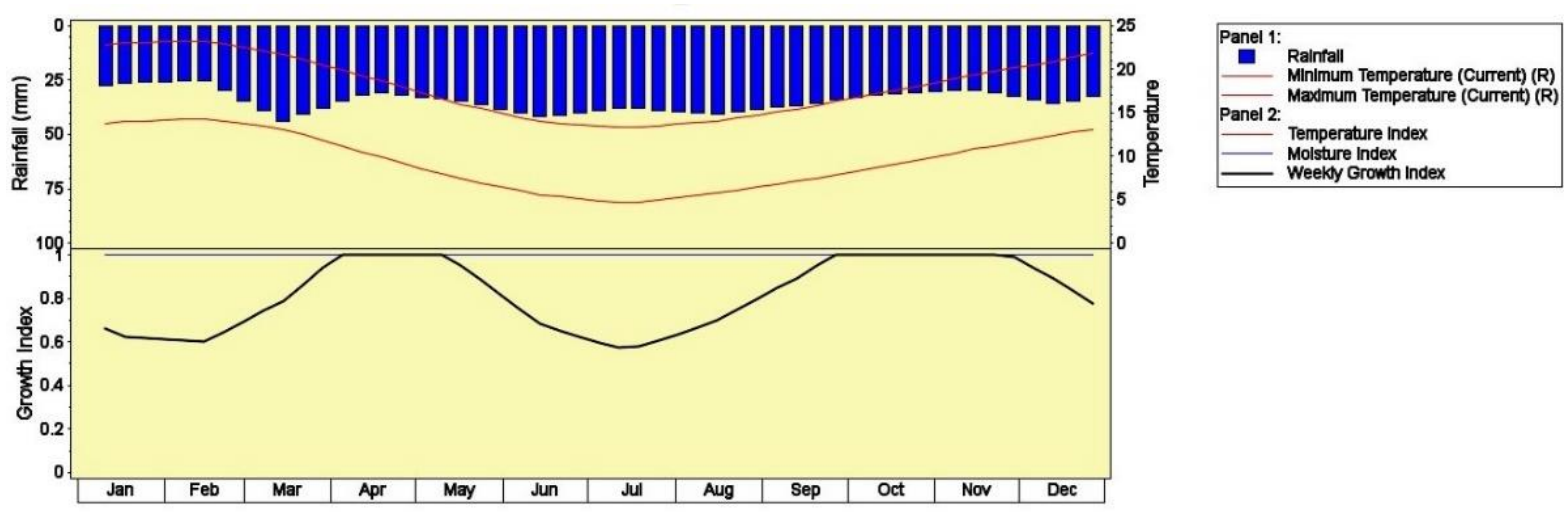

Figure 5. Weekly growth index and climate variables at Te Puke, Bay of Plenty, New Zealand for Psa produced by CLIMEX model.

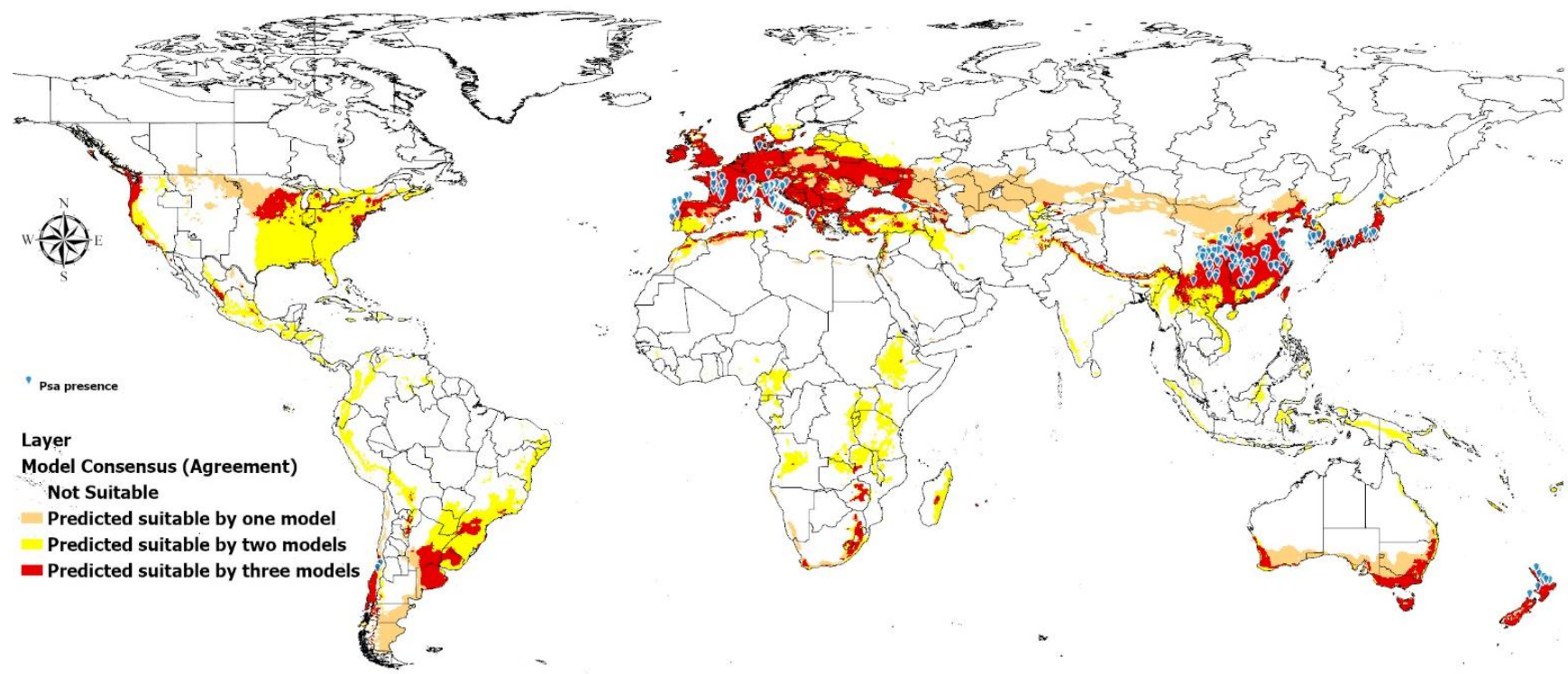

Figure 6. Model consensus (agreement) showing the hotspots, the areas which are predicted as suitable by two or three models for establishment of kiwifruit bacterial canker disease (Psa). The blue dots show the presence data.

\section{Discussion}

Only four studies have been developed to model Psa distribution using SDMs [40,43-45]. All these models focus on the potential distribution of Psa at a local scale and mostly rely on single models or the same type of models such as correlative models [43-45]. While some studies benefit from an ensemble approach [45], it is recommended that where possible, contributions to an ensemble model should be from different types of models and they should add information for building a better model [69]. The current study is the first to address the potential global distribution of an important plant pathogen using three different modelling approaches, a semi-mechanistic model (CLIMEX), a presencebackground correlative model (MaxEnt) and an ensemble of presence-pseudo absence models (MMF). To deal with uncertainty and benefit from different models and algorithm predictions, the models' outputs were combined into a consensus model which focuses on prediction agreements.

Each individual model showed a good fit to the current global distribution of Psa. While there was a high level of agreement among the three models on highly suitable areas in China, Australia, New Zealand, Europe, the USA and some parts of South America, 
compared to CLIMEX and MaxEnt, SVM projected larger areas in China, Central Asia and Europe as highly suitable.

The parameter values in the CLIMEX model were slightly different from the model developed in a preliminary study by [43]. Current CLIMEX model parameter values are more in agreement with the ranges mentioned in earlier studies [6,38]. The CLIMEX model indicated that the minimum temperature threshold (DV0) is $5^{\circ} \mathrm{C}$, which means the pathogen can stay active at this temperature. This is close to the finding by [44] where temperatures between $3.6-17.1^{\circ} \mathrm{C}$ in October were found to be conducive to Psa establishment in China. However, in the CLIMEX model presented in the EPPO report [40] and [37], a minimum temperature threshold of $10^{\circ} \mathrm{C}$ (DV0) was reported, which differs from the current findings and the information available on temperature needs of the pathogen. In the CLIMEX model presented in the EPPO report, the optimum temperature range is $20^{\circ} \mathrm{C}$ to $25^{\circ} \mathrm{C}$, which is higher than the current findings $\left(12{ }^{\circ} \mathrm{C}\right.$ to $\left.20^{\circ} \mathrm{C}\right)$ and those of previous studies regarding the optimum temperature range for Psa growth $[37,44]$. The response curves produced by the MaxEnt model (Figure 3), also indicated that the probability of pathogen establishment is the highest between 10 and $20^{\circ} \mathrm{C}$ with optimum being around $13{ }^{\circ} \mathrm{C}$. This is in close agreement with the current CLIMEX findings on suitable temperature range. Both the CLIMEX and MaxEnt models in the current study indicated that above $20^{\circ} \mathrm{C}$, the probability of Psa establishment starts to decrease, which is similar to the findings in [44] that showed the probability of Psa establishment rapidly decreases above $21.2^{\circ} \mathrm{C}$.

The soil moisture parameters in the current study are slightly higher than [40], which indicates that based on the current CLIMEX model, the pathogen is favored by higher soil moisture content compared with the CLIMEX model presented in the EPPO report. In CLIMEX, soil moisture is used as a proxy for rainfall and evapotranspiration, meaning that a higher soil moisture index implies increased rainfall and humidity affecting species growth [70]. Thus a higher soil moisture parameter value reflects more optimal rainfall, as spread of the foliar and stem pathogen Psa is not directly affected by soil moisture, and infection through roots is practically absent [71]. While the ensemble model developed in [45] showed that annual precipitation plays a minor role in Psa spread, similar to the model in [44], our study shows that precipitation plays an important role in Psa establishment. The sensitivity of Psa to rainfall has also been highlighted in other studies [48,72] and is in agreement with the high soil moisture (SM) values indicated in the current CLIMEX model (Table 1). The response of Psa to annual precipitation shows that while the pathogen is favored by moist conditions, excessive rain (above $1200 \mathrm{~mm} /$ year) will decrease the probability of pathogen establishment, probably because of the washout of inoculum [71].

The reasons for these differences in model outcomes might be due to coarser climate data and the fact that the previous CLMEX study was conducted when less information on the distribution of Psa was available. For example, Psa occurrences from Spain had not been used in the modelling effort mentioned in the EPPO report [40]. On the contrary, occurrence data for Perth in Western Australia were used in the EPPO study but these occurrence(s) proved to be erroneous later [72]. The number of Psa records used in model development can significantly affect results for species that are still spreading. In the current study we used 201 presence points while [43] used 82 presence points, explaining part of the differences found.

While the EI value estimated by the EPPO model [40] for New Zealand ranges from 15 to 35, indicating suitable to highly suitable areas for Psa establishment, the EI values estimated by the current model range from 50 to 90 suggesting an even higher suitability. Furthermore, our model projected the north of Iran (an area in which kiwifruit is grown commercially) as highly suitable but it was not projected as suitable or even marginally suitable by the CLIMEX model in the EPPO study [40]. To date there has been no report of Psa presence in this region. It should be noted, however, that one study mentions the presence of kiwifruit bacterial canker in Iran but refers to the causal agent as P. syringae pv. syringae [73]. In East Asia, where China is the major kiwifruit producer, all models 
perfectly fitted the occurrence data. At a national level, Yunnan and Guangxi province (where kiwifruit orchards cover 500 to 1000 ha respectively) were projected as suitable by all models. Although the number of predictor variables, the number of presence data and the resolution of the data used in [44] and 45 were different from the current study, overall, the model projection patterns for China are similar to those reported by [44] and 45 except that MMF projected larger areas in northern parts of China (Figure 4a-c). In Europe, all three models agreed on the suitability of some countries such as Italy, Spain, Portugal, France, Turkey, and Greece. The Trabazon Rize province in Turkey, where there are few reports of Psa presence, is predicted as suitable by all three models. The consensus model highlighted the areas where Psa establishment has been predicted by all three models. The areas of interest are California in the USA, northern parts of Iran, unaffected areas in Greece, Belgium, Denmark, and South Africa (Figure 6).

While prediction models, especially SDMs, can be valuable tools in assessing the risk of damaging invasive species, the limitation, caveats, and inherent uncertainties should be considered while interpreting their results [74-77]. In general, for species that may not have changed their environmental range, the presence profiles are expected to be confined to a small area in multidimensional space. The widespread predicted presence of Psa may be an indication that this species is still spreading, and that we may underestimate the full range of its potential distribution $[43,50]$. This result questions the validity of applying presence-only models such as MaxEnt that rely only on current knowledge of species that are still spreading. Moreover, it is important to note that the presence of a species may not be recorded for several reasons such as, (1) difficulty in detecting the species (an important consideration for plant pathogens due to their microscopic size), (2) evolutionary change of the pathogen, becoming more aggressive, and (3) the sudden appearance of new pathways aiding species spread.

Despite the limitation of individual models, the consensus model based on model agreement presented in this study, composed of three different types of models as recommended by [78], minimized the uncertainties and resulted in predictions that reflected the observed occurrences and the predictions from previous models $[40,43]$. The consensus model had the highest sensitivity and lowest false negative rate, with 199 out of 201 presence points lying within areas predicted as suitable. In situations involving important biosecurity threats such as Psa, it is important to minimize false negatives and aim for models with lower emission errors $[79,80]$. While over-prediction can also be an issue due to implementing unnecessary increased biosecurity readiness and response programs and strategies, prior knowledge of species biology can be used to prioritize areas which are most at risk so that when limited resources are available, they could be efficiently allocated in the right place at the right times.

As there are no known cures for Psa, the control of the disease should primarily rely on preventive measures. The results from predictive modelling suggest that optimal moisture supply, avoiding overhead irrigation, may contribute significantly to reduce Psa spread. In addition, management measures can include preventive application of chemicals such as copper-based compounds and antibiotics (streptomycin) to contain the pathogen spread. However, effective management would not be achieved without proper management procedures in the field including orchard hygiene, controlled access to orchards, monitoring grafting and use of nutrients for a healthier orchard. In addition, due to environmental concerns about application of chemicals, alternative methods such as biocontrol strategies using specific bacteriophages to eliminate Psa are currently under study and some already showed promising results [81].

Apart from some discrepancies among the models, all three models highlighted suitable areas in which Psa may establish. The high level of agreement between the SVM model (from the multimodel framework) and CLIMEX and MaxEnt increased confidence with respect to model projections for novel areas. These results are particularly valuable indicators for countries where Psa is currently reported from limited localities and for the USA, Iran, South Africa, Belgium, and Denmark, where Psa has not been reported. 
Supplementary Materials: The following supporting information can be downloaded at: https: //www.mdpi.com/article/10.3390/cli10020014/s1, Figure S1: Receiver operating characteristic (ROC) curve produced by MaxEnt for Psa; Table S1: The geographic coordinates of locations of Psa. Some presence data such as Australian points are excluded as they are now known to be a different pathovar; Table S2: The accuracy measures achieved by cross-validation (A) and bootstrapping (B) in Multi-Model Framework developed for Psa. Acronyms for models are: QDA = quadratic discriminant analysis, $\mathrm{NB}=$ naïve Bayes, $\mathrm{LDA}=$ linear discriminant analysis, $\mathrm{LOG}=$ logistic regression, $\mathrm{CART}=$ classification and regression tree, $\mathrm{CTREE}=$ conditional tree, $\mathrm{KNN}=\mathrm{K}$-nearest neighbour, $\mathrm{SVM}=$ support vector machine, and NNET = neural network.

Author Contributions: Conceptualization, S.P.W., H.A.N.-K.; formal analysis, H.A.N.-K.; funding acquisition, S.P.W.; investigation, H.A.N.-K.; methodology, H.A.N.-K., S.P.W., E.J.; project administration, S.P.W.; resources, H.A.N.-K., S.P.W., E.J.; software, S.P.W., H.A.N.-K.; supervision, S.P.W., E.J., S.L.H.V.; validation, H.A.N.-K., S.P.W., G.M.B.; visualization, H.A.N.-K.; writing-original draft, H.A.N.-K.; writing-review and editing, S.P.W., E.J., S.L.H.V., G.M.B., A.H.C.v.B. All authors have read and agreed to the published version of the manuscript.

Funding: This research was funded by Bio-Protection Research Centre and Better Border Biosecurity (B3), an unincorporated joint venture of four science agencies-Plant \& Food Research, AgResearch, Scion and the Bio-Protection Research Centre at Lincoln University-and three end-user partnersthe Ministry for Primary Industries, the Department of Conservation and the New Zealand Forest Owners Association.

Acknowledgments: We would like to thank Senait Senay, Tasha Shelby, Jennifer Pannell, Federico Tomasetto and Jo Berry for their valuable comments on early drafts of the manuscript, as well as David Logan from Plant \& Food Research and ZESPRI ${ }^{\circledR}$ International Limited for providing information regarding kiwifruit.

Conflicts of Interest: The authors declare no conflict of interest. The funders had no role in the design of the study; in the collection, analyses, or interpretation of data; in the writing of the manuscript, or in the decision to publish the results.

\section{References}

1. Renzi, M.; Copini, P.; Taddei, A.R.; Rossetti, A.; Gallipoli, L.; Mazzaglia, A.; Balestra, G.M. Bacterial canker on kiwifruit in Italy: Anatomical changes in the wood and in the primary infection sites. Phytopathology 2012, 102, 827-840. [CrossRef] [PubMed]

2. Vanneste, J.L. The scientific, economic, and social impacts of the New Zealand outbreak of bacterial canker of kiwifruit (Pseudomonas syringae pv. actinidiae). Annu. Rev. Phytopathol. 2017, 55, 377-399. [CrossRef] [PubMed]

3. Kim, G.H.; Jung, J.S.; Koh, Y.J. Occurrence and epidemics of bacterial canker of kiwifruit in Korea. Plant Pathol. J. 2017, 33, 351. [CrossRef] [PubMed]

4. Takikawa, Y.; Serizawa, S.; Ichikawa, T.; Tsuyumu, S.; Goto, M. Pseudomonas syringae pv. actinidiae pv. nov.: The causal bacterium of canker of kiwifruit in Japan. Ann. Phytopatb. Soc. Jpn. 1989, 55, 437-444.

5. Koh, Y.J.; Chung, H.J.; Cha, B.J.; Lee, D.H. Outbreak and spread of bacterial canker in kiwifruit. Plant Pathol. J. 1994, 10, 68-72.

6. Cheng, H.; Li, Y.; Wan, S.; Zhan, J.; Ping, Q.; Guo, L.; Jiahua, X. Pathogenic indentification of kiwifruit bacterial canker in Anhui. J. Anhui Agric. Univ. 1995, 22, 219-223.

7. Scortichini, M. Occurrence of Pseudomonas syringae pv. actinidiae on kiwifruit in Italy. Plant Pathol. 1994, 43, 1035-1038. [CrossRef]

8. Balestra, G.M.; Mazzaglia, A.; Spinelli, R.; Graziani, S.; Quattrucci, A.; Rossetti, A. Cancro batterico su Actinidia chinensis. L'Informatore Agrar. 2008, 38, 7576.

9. Renzi, M.; Mazzaglia, A.; Balestra, G.M. Widespread distribution of kiwifruit bacterial canker caused by the European Pseudomonas syringae pv. actinidiae genotype in the main production areas of Portugal. Phytopathol. Mediterr. 2012, 51, 402-409.

10. Balestra, G.M.; Mazzaglia, A.; Quattrucci, A.; Renzi, M.; Ricci, L.; Rossetti, A. Increased spread of bacterial canker of kiwifruit in Italy. Inf. Agrar. 2009, 65, 58-60.

11. Balestra, G.M.; Renzi, M.; Mazzaglia, A. First report of bacterial canker of Actinidia deliciosa caused by Pseudomonas syringae pv. actinidiae in Portugal. New Dis. Rep. 2010, 22, 10. [CrossRef]

12. Balestra, G.M.; Renzi, M.; Mazzaglia, A. First report of Pseudomonas syringae pv. actinidiae on kiwifruit plants in Spain. New Dis. Rep. 2011, 24, 10. [CrossRef]

13. Everett, K.R.; Taylor, R.K.; Romberg, M.K.; Rees-George, J.; Fullerton, R.A.; Vanneste, J.L.; Manning, M.A. First report of Pseudomonas syringae pv. actinidiae causing kiwifruit bacterial canker in New Zealand. Australas. Plant Dis. Notes 2011, 6, 67-71. [CrossRef]

14. EPPO. First report of Pseudomonas syringae pv. actinidiae in Chile. EPPO Report. Serv. 2011, 3, 55. 
15. Dreo, T.; Pirc, M.; Ravnikar, M.; Žežlina, I.; Poliakoff, F.; Rivoal, C.; Nice, F.; Cunty, A. First report of Pseudomonas syringae pv. actinidiae, the causal agent of bacterial canker of kiwifruit in Slovenia. Plant Dis. 2014, 98, 1578. [CrossRef]

16. EPPO. First report of Pseudomonas syringae pv. actinidiae in Switzerland. EPPO Rep. Serv. No. 8 2011, 6, 67-71.

17. Bastas, K.K.; Karakaya, A. First report of bacterial canker of kiwifruit caused by Pseudomonas syringae pv. actinidiae in Turkey. Mol. Plant Pathol. 2012, 13, 631-640. [CrossRef]

18. Vanneste, J.L.; Poliakoff, F.; Audusseau, C.; Cornish, D.A.; Paillard, S.; Rivoal, C.; Yu, J. First report of Pseudomonas syringae pv. actinidiae, the causal agent of bacterial canker of kiwifruit in France. Mol. Plant Pathol. 2012, 13, 631-640. [CrossRef]

19. EPPO. First report of Pseudomonas syringae pv. actinidiae in Germany. EPPO Rep. Serv. No. 9. 2013, p. 185, no. 09-2013. Available online: https:/ /gd.eppo.int/reporting/article-2647.2013 (accessed on 5 December 2013).

20. Holeva, M.; Glynos, P.; Karafla, C. First report of bacterial canker of kiwifruit caused by Pseudomonas syringae pv. actinidiae in Greece. Plant Dis. 2015, 99, 723. [CrossRef]

21. Mazzaglia, A.; Turco, S.; Taratufolo, M.; Tatì, M.; Rahi, Y.J.; Gallipoli, L.; Balestra, G. Improved MLVA typing reveals a highly articulated structure in Pseudomonas syringae pv. actinidiae populations. Physiol. Mol. Plant Pathol. 2021, 114, 101636. [CrossRef]

22. Ciarroni, S.; Gallipoli, L.; Taratufolo, M.C.; Butler, M.I.; Poulter, R.T.; Pourcel, C.; Vergnaud, G.; Balestra, G.M.; Mazzaglia, A. Development of a multiple loci variable number of tandem repeats analysis (MLVA) to unravel the intra-pathovar structure of Pseudomonas syringae pv. actinidiae populations worldwide. PLoS ONE 2015, 10, e0135310. [CrossRef] [PubMed]

23. He, R.; Liu, P.; Jia, B.; Xue, S.; Wang, X.; Hu, J.; Al Shoffe, Y.; Gallipoli, L.; Mazzaglia, A.; Balestra, G.M. Genetic diversity of Pseudomonas syringae pv. actinidiae strains from different geographic regions in China. Phytopathology 2019, 109, 347-357. [CrossRef] [PubMed]

24. Cunty, A.; Poliakoff, F.; Rivoal, C.; Cesbron, S.; Fischer-Le Saux, M.; Lemaire, C.; Jacques, M.-A.; Manceau, C.; Vanneste, J Characterization of Pseudomonas syringae pv. actinidiae (P sa) isolated from France and assignment of Psa biovar 4 to a de novo pathovar: Pseudomonas syringae pv. actinidifoliorum pv. nov. Plant Pathol. 2015, 64, 582-596. [CrossRef]

25. Froud, K.; Everett, K.; Tyson, J.; Beresford, R.; Cogger, N. Review of the risk factors associated with kiwifruit bacterial canker caused by Pseudomonas syringae pv actinidiae. N. Z. Plant Prot. 2015, 68, 313-327. [CrossRef]

26. KVH. Kiwifruit Vine Health Psa Statistics Report. Available online: https://kvh.org.nz/protocols-movement-controls/mapsand-stats (accessed on 5 December 2013).

27. KVH. Kiwifruit Vine Health Psa Statistics Report. Available online: https://kvh.org.nz/assets/documents/Protocols-andmovement-controls-tab/Maps-and-Stats/KVH-Psa-statistics-06122019.pdf (accessed on 5 December 2021).

28. Ushiyama, K. Studies on the epidemics and control of bacterial canker of kiwifruit caused by Pseudomonas syringae pv. actinidiae. Bull. Kanagawa Hortic. Exp. Stn. 1993, 43, 1-76.

29. Gallipoli, L.; Hu, J.; Pu, L.; Speranza, S.; Mazazaglia, A.; Zhu, L.; Balestra, G.M. Two potential vectors, Nephotettix bipunctatus and Firmiana simplex to spread Pseudomonas syringae pv. actinidiae causing kiwifruit bacterial canker. In Proceedings of the 1st International Symposium on Bacterial Canker of Kiwifruit (Psa), Mt. Maunganui, Tauranga, New Zealand, 19-22 November 2013; p. 73.

30. Liu, P.; Xue, S.; He, R.; Hu, J.; Wang, X.; Jia, B.; Gallipoli, L.; Mazzaglia, A.; Balestra, G.M.; Zhu, L. Pseudomonas syringae pv actinidiae isolated from non-kiwifruit plant species in China. Eur. J. Plant Pathol. 2016, 145, 743-754. [CrossRef]

31. Quattrucci, A.; Renzi, M.; Rossetti, A.; Ricci, L.; Taratufolo, M.C.; Mazzaglia, A.; Balestra, G.M. Cancro batterico del kiwi verde: Nuove strategie di controllo. L'informatore Agrar. 2010, 16, 53-58.

32. Ferrante, P.; Scortichini, M. Identification of Pseudomonas syringae pv. actinidiae as causal agent of bacterial canker of yellow kiwifruit (Actinidia chinensis Planchon) in central Italy. J. Phytopathol. 2009, 157, 768-770. [CrossRef]

33. Greer, G.; Saunders, C. The Costs of Psa-V to the New Zealand Kiwifruit Industry and the Wider Community; Agribusiness and Economics Research Unit Report; Lincoln University: Lincoln, New Zealand, 2012.

34. Birnie, D.; Livesey, A. Lessons learned from the response to Psa-V. Sapere Res. 2014. Available online: https://kvh.org.nz/vdb/ document/100538 (accessed on 1 December 2021).

35. Serizawa, S.; Ichikawa, T.; Takikawa, Y.; Tsuyumu, S.; Goto, M. Occurrence of bacterial canker of kiwifruit in Japan: Description of symptoms, isolation of the pathogen and screening of bactericides. Ann. Phytopathol. Soc. Jpn. 1989, 55, 427-436. [CrossRef]

36. Donati, I.; Mauri, S.; Buriani, G.; Cellini, A.; Spinelli, F. Role of Metcalfa pruinosa as a vector for Pseudomonas syringae pv. actinidiae. Plant Pathol. J. 2017, 33, 554. [CrossRef] [PubMed]

37. Serizawa, S.; Ichikawa, T. Epidemiology of bacterial canker of kiwifruit. 4. Optimum temperature for disease development on new canes. Ann. Phytopathol. Soc. Jpn. 1993, 59, 694-701. [CrossRef]

38. Serizawa, S.; Ichikawa, T. Epidemiology of bacterial canker of kiwifruit, 3: The seasonal changes of bacterial population in lesions and of its exudation from lesion. Ann. Phytopathol. Soc. Jpn. 1993, 59, 46. [CrossRef]

39. Beresford, R.; Tyson, J.; Henshall, W. Development and validation of an infection risk model for bacterial canker of kiwifruit, using a multiplication and dispersal concept for forecasting bacterial diseases. Phytopathology 2017, 107, 184-191. [CrossRef]

40. EPPO. Final Pest Risk Analysis for Pseudomonas Syringae pv. Actinidiae 12-17928; European and Mediterranean Plant Protection Organization: Paris, France, 2012; p. 50.

41. Yao, L.I.; Heyuan, C.; Shumiao, F.; Zihua, Q. Prevalent forecast of kiwifruit bacterial canker caused by Pseudomonas syringae pv. actinidiae. Chin. J. Appl. Ecol. 2001, 3, 355-358. 
42. Tyson, J.; Rees-George, J.; Curtis, C.; Manning, M.; Fullerton, R. Survival of Pseudomonas syringae pv. actinidiae on the orchard floor over winter. N. Z. Plant Prot. 2012, 65, 25-28. [CrossRef]

43. Narouei Khandan, H.A.; Worner, S.P.; Jones, E.E.; Villjanen-Rollinson, S.L.H.; Gallipoli, L.; Mazzaglia, A.; Balestra, G.M. Predicting the potential global distribution of Pseudomonas syringae pv. actinidiae (Psa). N. Z. Plant Prot. 2013, 66, $184-193$.

44. Wang, R.; Li, Q.; He, S.; Liu, Y.; Wang, M.; Jiang, G. Modeling and mapping the current and future distribution of Pseudomonas syringae pv. actinidiae under climate change in China. PLoS ONE 2018, 13, e0192153. [CrossRef]

45. Qin, Z.; Zhang, J.; Jiang, Y.; Wang, R.; Wu, R. Predicting the potential distribution of Pseudomonas syringae pv. actinidiae in China using ensemble models. Plant Pathol. 2020, 69, 120-131. [CrossRef]

46. Do, K.S.; Chung, B.N.; Joa, J.H. D-PSA-K: A model for estimating the accumulated potential damage on kiwifruit canes caused by bacterial canker during the growing and overwintering seasons. Plant Pathol. J. 2016, 32, 537. [CrossRef]

47. Kim, K.H.; Son, K.; Koh, Y. Adaptation of the New Zealand Psa Risk Model for forecasting kiwifruit bacterial canker in Korea Plant Pathol. 2018, 67, 1208-1219. [CrossRef]

48. Kim, K.-H.; Koh, Y.J. An integrated modeling approach for predicting potential epidemics of bacterial blossom blight in kiwifruit under climate change. Plant Pathol. J. 2019, 35, 459. [CrossRef] [PubMed]

49. Kim, K.-H.; Koh, Y.J. Development of a Maryblyt-based forecasting model for kiwifruit bacterial blossom blight. Res. Plant Dis. 2015, 21, 67-73. [CrossRef]

50. Narouei-Khandan, H.; Worner, S.; Viljanen, S.; van Bruggen, A.; Jones, E. Projecting the suitability of global and local habitats for myrtle rust (Austropuccinia psidii) using model consensus. Plant Pathol. 2020, 69, 17-27. [CrossRef]

51. Narouei-Khandan, H.A.; Halbert, S.E.; Worner, S.P.; van Bruggen, A.H. Global climate suitability of citrus huanglongbing and its vector, the Asian citrus psyllid, using two correlative species distribution modeling approaches, with emphasis on the USA. Eur. J. Plant Pathol. 2016, 144, 655-670. [CrossRef]

52. Kriticos, D.J.; Morin, L.; Leriche, A.; Anderson, R.C.; Caley, P. Combining a climatic niche model of an invasive fungus with its host species distributions to identify risks to natural assets: Puccinia psidii Sensu Lato in Australia. PLoS ONE 2013, 8, e64479. [CrossRef]

53. Kriticos, D.J.; Webber, B.L.; Leriche, A.; Ota, N.; Macadam, I.; Bathols, J.; Scott, J.K. CliMond: Global high-resolution historical and future scenario climate surfaces for bioclimatic modelling. Methods Ecol. Evol. 2012, 3, 53-64. [CrossRef]

54. Hutchinson, M.; Xu, T.; Houlder, D.; Nix, H.; McMahon, J. ANUCLIM 6.0 User's Guide; Fenner School of Environment and Society, Australian National University: Canberra, Austrilia, 2009.

55. Elith, J. Predicting Distributions of Invasive Species. 2013. Available online: http://arxiv.org/abs/1312.0851 (accessed on 1 December 2021).

56. Stephens, A.E.; Kriticos, D.J.; Leriche, A. The current and future potential geographical distribution of the oriental fruit fly, Bactrocera dorsalis (Diptera: Tephritidae). Bull. Entomol Res. 2007, 97, 369-378. [CrossRef]

57. Beddow, J.M.; Hurley, T.M.; Kriticos, D.J.; Pardey, P.G. Measuring the Global Occurrence and Probabilistic Consequences of Wheat Stem Rust. St. Paul, MN, HarvestChoice, April 2013. pp. 1-24. Available online: https://www.instepp.umn.edu/products / measuring-global-occurrence-and-probabilistic-consequences-wheat-stem-rust (accessed on 1 December 2021).

58. Venette, R.C.; Cohen, S.D. Potential climatic suitability for establishment of Phytophthora ramorum within the contiguous United States. For. Ecol. Manage. 2006, 231, 18-26. [CrossRef]

59. Pattison, R.R.; Mack, R.N. Potential distribution of the invasive tree Triadica sebifera (Euphorbiaceae) in the United States: Evaluating CLIMEX predictions with field trials. Glob. Change Biol. 2008, 14, 813-826. [CrossRef]

60. Poutsma, J.; Loomans, A.J.M.; Aukema, B.; Heijerman, T. Predicting the potential geographical distribution of the harlequin ladybird, Harmonia axyridis, using the CLIMEX model. BioControl 2008, 53, 103-125. [CrossRef]

61. Senaratne, K.A.D.; Palmer, W.A.; Sutherst, R.W. Use of CLIMEX modelling to identify prospective areas for exploration to find new biological control agents for prickly acacia. Aust. J. Entomol. 2006, 45, 298-302. [CrossRef]

62. Elith, J.; Graham, C.H.; Anderson, R.P.; Dudík, M.; Ferrier, S.; Guisan, A.; Hijmans, R.J.; Huettmann, F.; Leathwick, J.R.; Lehmann, A. Novel methods improve prediction of species' distributions from occurrence data. Ecography 2006, 29, 129-151. [CrossRef]

63. Elith, J.; Phillips, S.J.; Hastie, T.; Dudík, M.; Chee, Y.E.; Yates, C.J. A statistical explanation of MaxEnt for ecologists. Divers. Distrib. 2011, 17, 43-57. [CrossRef]

64. Merow, C.; Smith, M.J.; Silander, J.A. A practical guide to MaxEnt for modeling species' distributions: What it does, and why inputs and settings matter. Ecography 2013, 36, 1-12. [CrossRef]

65. Syfert, M.M.; Smith, M.J.; Coomes, D.A. The effects of sampling bias and model complexity on the predictive performance of MaxEnt species distribution models. PLoS ONE 2013, 8, e55158. [CrossRef]

66. Worner, S.P.; Ikeda, T.; Leday, G.; Zealand, N.; Joy, M. Surveillance Tools for Freshwater Invertebrates. MAF Biosecurity Tech. Pap. 2010. Available online: http:/ / citeseerx.ist.psu.edu/viewdoc/download?doi=10.1.1.459.1082\&rep=rep1\&type=pdf $($ accessed on 1 December 2021).

67. Radosavljevic, A.; Anderson, R.P. Making better Maxent models of species distributions: Complexity, overfitting and evaluation. J. Biogeogr. 2013, 41, 629-643. [CrossRef] 
68. Biosecurity Australia. Final Pest risk Analysis Report for Pseudomonas Syringae pv. Actinidiae Associated with Actinidia (Kiwifruit)Propagative Material; Department of Agriculture, Fisheries and Forestry: Canberra, Australia, 2011. Available online: https://www.awe.gov.au/biosecurity-trade/policy/risk-analysis/memos/2011/baa_2011-22-final. (accessed on 1 December 2021).

69. Wolpert, D.H. Stacked generalization. Neural Netw. 1992, 5, 241-259. [CrossRef]

70. Sutherst, R.W.; Maywald, G.F.; Kriticos, D.J. CLIMEX Version 3: User's Guide. South Yarra: Hearne Scientific Software. 2007. Available online: http:/ /hdl.handle.net/102.100.100/127529?index=1 (accessed on 1 December 2021).

71. Donati, I.; Cellini, A.; Sangiorgio, D.; Vanneste, J.L.; Scortichini, M.; Balestra, G.M.; Spinelli, F. Pseudomonas syringae pv. actinidiae: Ecology, infection dynamics and disease epidemiology. Microb. Ecol. 2020, 80, 81-102. [CrossRef]

72. Chapman, J.; Taylor, R.; Weir, B.; Romberg, M.; Vanneste, J.; Luck, J.; Alexander, B. Phylogenetic relationships among global populations of Pseudomonas syringae pv. actinidiae. Phytopathology 2012, 102, 1034-1044. [CrossRef] [PubMed]

73. Mazarei, M.; Mostofipour, P. First report of bacterial canker of kiwifruit in Iran. Plant Pathol. 1994, 43, 1055-1056. [CrossRef]

74. Araújo, M.B.; Whittaker, R.J.; Ladle, R.J.; Erhard, M. Reducing uncertainty in projections of extinction risk from climate change. Glob. Ecol. Biogeogr. 2005, 14, 529-538. [CrossRef]

75. Watling, J.I.; Brandt, L.A.; Bucklin, D.N.; Fujisaki, I.; Mazzotti, F.J.; Romanach, S.S.; Speroterra, C. Performance metrics and variance partitioning reveal sources of uncertainty in species distribution models. Ecol. Model. 2015, 309, 48-59. [CrossRef]

76. Narouei-Khandan, H.A.; Harmon, C.L.; Harmon, P.; Olmstead, J.; Zelenev, V.V.; van der Werf, W.; Worner, S.P.; Senay, S.D.; van Bruggen, A.H.C. Potential global and regional geographic distribution of Phomopsis vaccinii on Vaccinium species projected by two species distribution models. Eur. J. Plant Pathol. 2017, 148, 919-930. [CrossRef]

77. van Bruggen, A.; West, J.; Van der Werf, W.; Potting, R.; Gardi, C.; Koufakis, I.; Zelenev, V.; Narouei-Khandan, H.; Schilder, A.; Harmon, P. Input data needed for a risk model for the entry, establishment and spread of a pathogen (Phomopsis vaccinii) of blueberries and cranberries in the EU. Ann. Appl. Biol. 2018, 172, 126-147. [CrossRef]

78. Araujo, M.B.; New, M. Ensemble forecasting of species distributions. Trends Ecol. Evol. 2007, 22, 42-47. [CrossRef]

79. Webber, B.L.; Yates, C.J.; Le Maitre, D.C.; Scott, J.K.; Kriticos, D.J.; Ota, N.; McNeill, A.; Le Roux, J.J.; Midgley, G.F. Modelling horses for novel climate courses: Insights from projecting potential distributions of native and alien Australian acacias with correlative and mechanistic models. Divers. Distrib. 2011, 17, 978-1000. [CrossRef]

80. Ward, D.F. Modelling the potential geographic distribution of invasive ant species in New Zealand. Biol. Invasions 2007, 9, 723-735. [CrossRef]

81. Pereira, C.; Costa, P.; Pinheiro, L.; Balcão, V.M.; Almeida, A. Kiwifruit bacterial canker: An integrative view focused on biocontrol strategies. Planta 2021, 253, 1-20. [CrossRef] 